\title{
THE COOPERATION AMID PROBLEMS: TURKISH-AMERICAN RELATIONS IN THE 1980s
}

NASUH USLU

\section{Introduction}

The uneasy relationship between Turkey and the United States was further exacerbated by the resumption of poppy cultivation by the Turkish government in June 1974. The Americans, who believed that the main cause of the American drug addiction problem was the smuggling of Turkish opium into the United States, perceived this Turkish initiative as an antiAmerican act. While Congress was busy with trying to cut off aid to Turkey as a retaliation, a coup occurred in Cyprus on 15 July 1974, bringing about the Turkish intervention to the island. In both cases the American government inclincd toward accepting the new situations and avoided showing strong responses which would alienate both the Greeks and the Turks. Imposing of an arms embargo on Turkey by the U.S. Congress, starting on 5 February 1975, was mainly a result of a power competition between the U.S. administration and Congress, which was detcrmined to make the arrogant rulers respect the rulc of law and to regain its power in foreign policy-making. The unhappiness of congressmen on the Turkish poppy decision and propaganda activities of the Greek lobby, too, played role in the embargo decision.

The American administration was opposed to the embargo on the ground that it would harm America's military cooperation with Turkey, which was vital for U.S. global security interests. However, American rulers also used the matter to force Turkish leaders to make concessions in the Cyprus question. In the Turkish eyes, Cyprus and U.S.-Turkish military relations were separate issues and should not be linked to each other. In this context, they saw the embargo as a hostile act of the United States, which 
undermined the capability, preparedness and effectiveness of the Turkish armed forces. On 25 July 1975 the Turkish government declared that the Defence Cooperation Agreement of 1969 and all other related agreements between the two countries lost their legal validity and that all U.S. military installations in Turkey passed under the full control and custody of the Turkish authorities. ${ }^{1}$ Thus, relations between Turkey and the United States hit their lowest level though their alliance continued within the NATO framework. After long intensive efforts of the U.S. administration, the Senate voted to repeal the embargo on 26 July 1978 and the House followed through on August 1. In return, on 9 October the Turkish government terminated the suspension measures implemented in U.S. bases and facilities. Whether the two states would manage in the 1980 s to return to cordial relations had gained importance at that point.

\section{Military Relations}

The reasons for formation and continuity of the Turkish-American military alliance were also valid in the 1980s. Turkish leaders remained keen to continue the alliance because they saw it as a warranty of Turkish security against the Soviet Union and other possible thrcats, as a source of military and economic assistance and as a guarantee for westernising Turkey and making her a part of the Western world. Turkey's stratcgic importance for U.S. interests in the Middle East and the Eastern Mediterranean, Turkey's contribution to NATO and the desire to keep Turkey within the Western camp so as not to lose prestige vis-à-vis the Soviet bloc were the main reasons for the Americans to maintain their alliance with Turkey.

The framework of Turkish-American military relations was drawn with a Defence and Economic Cooperation Agrecment (DECA), signed on 29 March $1980 .^{2}$ It was a five-year executive agreement, renewable annually, which would implement the NATO treaty. The United States undertook to provide defence equipment, services, and training to Turkish forces; Turkey, in return, authorised the USA to maintain forces and carry out military activities at specificd installations. A U.S.-Turkish Joint Commission was created as a mechanism for discussing how to use Turkey's resources for its security objectives. The agreement had been negotiated by the successive leftist and rightist governments under Bülent Ecevit and Süleyman Demirel and it was to be implemented by the military regime headed by General Kenan Evren. This demonstrated 'once again the non-partisan character of Turkey's foreign policy and of its commitment to the special relationship

\footnotetext{
${ }^{1}$ Cumhuriyet, 26.07 .1975 .

${ }^{2}$ R. C. Campany, Turkey and the United States: the Arms Embargo Period, New York: Praeger, 1986, pp. 103-123.
} 
with the United States'. ${ }^{3}$ Turkey's military rulers further proved their goodwill by accepting NATO's American commander General Rogers' proposal of allowing the retum of Greece to NATO's military structure in return for abolition of Greece's single-handed control over air traffic in the Aegean. Nevertheless, Greck Prime Minister Papandreou did not implement this plan and Gencral Rogers did not make serious efforts to force the Greeks in this direction.

The Amcricans showed their friendship by not criticising the Turkish military coup on 12 September 1980 unlike the other Westem powers. The statement of the U.S. State Department on the same day expressed worry on the fall of an elected government by military commanders but it stated that Turkey had been facing terrorism and economic difficulties for a number of years and that Turkish military commanders promised to return to party politics. The statement also announced that American military and economic aid to Turkey would continuc. 4

The Özal government, which came to power in November 1983, did its best to continue the DECA though it had some reservations on the implementation and content of the agreement. Its main complaints were as follows: (a) The United States had unfairly observed a 7:10 ratio in determining aid to Greece and Turkey. (b) American aid to Turkey had been linked to the Cyprus question, Turkey's human rights record and the claim that the Ottoman Empire massacred the Armenians at the beginning of this century. (c) The discussion of these matters by Congress during aid bill negotiations had alienated Turkish public opinion. (d) Though the DECA included economic cooperation, the United States had not provided suitable trade conditions especially to Turkish textiles. ${ }^{5}$

Three months before the first five-year period of the DECA ended (17 September 1985), the Özal government called the Americans to negotiate changes in the agreement. It was interesting that though Turkish leaders were not happy with the DECA and were demanding radical changes in it, they allowed it to be extended on an annual basis 'so as to allow for broader negotiations. ${ }^{6}$ At the end what Turkey got was not a new agreement but supplementary letters which extended the DECA, including U.S. base rights, to 1990 . The letters were initialled on 12 December 1986 and exchanged on 16 March 1987. They included almost the same terms as in the DECA and

${ }^{3}$ D. A. Rustow, Turkey: America's Forgotten Ally, New York: Council on Foreign Relations, 1987, pp. 104-105.

${ }^{4}$ Fahir Armaoğlu, 20. Yüzyıl Slyası Tarihı, Vol. П, Ankara: Türkiye I\$ Bankası, 1994, p. 297.

${ }^{5}$ Ibid., pp. 304-305.

${ }^{6}$ Rustow, Turkey, p. 106. 
did not bring any radical changes or any new commitments for the United States. On the other hand, Congress' cutting of military aid to Turkey from 913 million dollars to 525 million dollars led the Turkish government to suspend ratification of the letters. President Evren's planned visit to Washington, which would have been the first by a Turkish president in twenty-five years was also postponed. ${ }^{7}$ The letters were finally ratified by the Turkish government on 28 February 1988, on the eve of President Evren's delayed visit to the USA. The DECA would expire at the end of December 1990 and Turkey should inform the United States of her demands and complaints before 17 September. However, Turkey was having a close relationship with the United States in the aftermath of the Iraqi occupation of Kuwait and Turkish leaders did not want to spoil this cooperation by making nuisance on the DECA. Thus, the agreement was extended for five years automatically and quietly. Although Turkish rulers had always felt resentment toward the American indifference to Turkish worries and complaints on the DECA, they provided the continuity of the agreement under all conditions. This could be explained with the Turkish determination to have the alliance, support and assistance of the United States.

\section{Military Assistance}

One of the major problems between Turkey and the USA was that the U.S. Congress had a pattern of conditioning aid on good Turkish behaviour on the Cyprus and Armenian questions and limiting it to a ratio (7:10) between the assistance given to Greece and Turkey. The 1978 amendment to the Foreign Assistance Act of 1961, which lifted the arms embargo, required that U.S. aid to Grecce and Turkey should be designed to maintain the present balance of military strength in the Acgean region. A Congressional majority, who accepted the views of the Greek government in its problems with Turkey and who had significant Greek-Amcrican constituencies, decided that the Acgean status quo could be protected if Greece received 7 dollars in aid every 10 dollars going to Turkey. ${ }^{8}$ Although the $7: 10$ ratio was not spelled out in any legislation, Congress maintained it in all American aid bills concerning Turkey and Greece in the 1980s in spite of the administration's aid requests diverging from the ratio. The official views of the Turkish and American administrations were that assistance should be provided to both Grecce and Turkey in accordance with their own particular NATO-related requirements without regard to any mechanical ratio. To

\footnotetext{
${ }^{7}$ P. B. Henze, 'Out of Kilter: Greeks, Turks and U.S. Policy', National Interest, Vol. 8, 1987, p. 82; Monteagle Stearns, Entangled Allies: US Policy Toward Greece, Turkey and Cyprus, New York: Council on Foreign Relations, 1992, pp. 43 and 167n.

${ }^{8}$ Stearns, Entangled Allies, pp. 40-41; R. N. Haass, 'Managing NATO's Weakest Flank: the United States, Greece and Turkey', ORBIS, Vol. 30 (3), 1986, pp. 467n.
} 
determine the balance of military forces in the Aegean, stipulated by the law, a whole range of factors from geography and existing inventories to troop quality and tactics would have to be identified and weighed. However, while the American rulers chose the easy way by blaming Congress on the nonrealisation of the projected amounts of aid for Turkey, Turkish leaders used this fact to justify tight control of U.S. military activities on Turkish territory. ${ }^{9}$

Since the Amcrican policy-makers saw a strong and stable Turkey in the national interest of the United States, it was essential for them to continue a strong program of economic and security assistance to Turkey. The Turkish armed forces, the second largest standing army in NATO and an important factor in its region for the Western security, should be modemised and Turkey should be compensated for the indignities and material losses suffered during the arms embargo. ${ }^{10}$ Particularly the Reagan administration placed Turkey high on the priority list for increased sccurity assistance, calling its needs 'urgent', 'pressing', and 'most demanding'. In 1983, the Pentagon estimated that bringing Turkish forces up to minimum NATO standards would take $\$ 18$ billion over 13 years. Doubling of U.S. security assistance to Turkey during the Reagan administration showed the seriousness of American rulers on their security relationship with Turkey. ${ }^{11}$ The modernisation of the Turkish army had been a prime objective for the following administrations, too.

The difficulty of reconciling the U.S. dependence on Turkish military forces and bases with the continuing Turkish need for U.S. economic and military assistance was one negative element causing irritations and conflict in U.S.-Turkish relations. Turkish leaders naturally wanted to maximise the aid received from the United States and to make the conditions attached to it as favourable as possible. Although the U.S. aid to Turkey was substantial by any standard and Turkey became the third largest recipient of the U.S. aid at one point, the aid levels appropriated by Congress were still far short of Turkish needs and did not fill the gap between Turkey's current capabilities and NATO responsibilities. As the Americans resisted the excessive Turkish aid demands and the Turks were careful about the conditions of the aid, this

\footnotetext{
${ }^{9}$ Stearns, Entangled Allies, pp. 42-44; Haass, 'Managing...', pp. 467n.

${ }^{10}$ Stcarns, Entangled Allies, p. 40; Richard Burt, 'Turkey and Reagen Administration in G. S. Harris (ed.), The Middle East in TurkishAmerican Relations, Washington: The Heritage Foundation, 1985, p. 20; Barry Rubin. 'U.S. Middle East Policy in the Turkish Context' in ibid., p. 78.

11 B. R. Kuniholm, 'Turkey in the World' in ibid., p. 11; Richard Perle, 'Turkey and U.S. Military Assistance' in Ibid., p. 23; E. B. Laipson, 'U.S.Turkish Friendly Friction', Journal of Defense and Diplomacy, Vol. $3(9), 1985$, p. 22.
} 
resulted in difficult and bitter negotiations, which often ended in disappointment and resentment in both sides. ${ }^{12}$ The conditioning of the U.S. aid to the Cyprus and Armenian issues particularly undermined the Turkish confidence in the U.S. capacity to provide a powerful program for Turkish needs that was not hostage to Congress's arbitrary use of power of the purse. At the end, a political process which hurt their national pride led the Turks to feel little satisfaction over the substantial aid, but instead to fill with resentment. ${ }^{13}$ As the Congress debates on aid bills made Greece and Turkey professional lobbyists, the U.S. executive and legislative branches, too, were drawn into the Greek-Turkish contest, hampering the American ability to establish realistic alliance relations with the two states. ${ }^{14}$

From the start of the DECA the United States allocated to Turkey annually about $\$ 700$ million through its Military Assistance Program, Economic Support Fund and International Educational Training Program. Meanwhile, some methods were used to reduce the impact of the 7:10 formula: increased economic aid, better financial terms, use of NATO infrastructure funds and grants of excess equipment. ${ }^{15}$ Early in 1983, the American government asked for a total package of \$ 930 million for Turkey for the fiscal year 1984. It was an open challenge to Congress' 7:10 ratio. But within one month, the initial request of $\$ 280$ million for Greece was amended to $\$ 500$ million and $\$ 930$ million for Turkey was reduced to $\$ 715$ million to restore the ratio. ${ }^{16}$ The U.S. aid for Turkey reached its peak in 1985 by totalling $\$ 878$ million in comparison with $\$ 200$ million in 1979 , but in the following years it materialised around $\$ 500$ million. The reduction of the total aid from an administration request for $\$ 913.5$ million to $\$ 525.3$ million for the fiscal year 1988 led the Turkish government to suspend temporarily ratification of the letters on extending the DECA, causing an impasse in U.S.-Turkish relations. ${ }^{17}$ Even the reinforcement of Turkey's importance for the United States during the Gulf crisis of 19901991 were not powerful enough to increase the aid substantially. The last aid

12 George McGhee, The US-Turkish-NATO-Middle East Connection, London: Macmillan, 1990, pp. 168-169.

${ }^{13}$ Kuniholm, Turkey in the World', p. 12; Perle, 'Turkey and...', p. 23; Henze, 'Out of Kilter', p. 82; Haass, 'Managing... 2 pp. 466-467.

${ }^{14}$ Stearns, Entangled Allies, pp. 49-50.

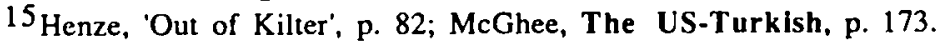

${ }^{16} \mathrm{E}$. B. Laipson, 'Turkey and the US Congress' in Harris (ed.), The Middle East, pp. 29-30; B. R. Kuniholm, Turkey and NATO: Past, Present and Future', OR BIS, Summer 1983, p. 442; L. H. Bruce, 'Cyprus: A Last Chance', Foreign Policy, No. 58, 1985, p. 118.

17 Stearns, Entangled Allies, pp. 43 and 167 n. 
request of the Bush administration was reduced from $\$ 543$ million to $\$ 450$ million as credits by Congress. 18

\section{Turkey's Strategic Importance}

Turkey continued to have a great strategic importance for the United States throughout the 1980s. Although American policy analysts tended to class Turkey along with Spain and Portugal in NATO's southern flank, Turkey's central importance for the USA stemmed from the fact that she was an indispensable strategic factor linking the Western world with the turbulent Middle East and was a stepping stone or a barrier to gaining access to the region. The American policy-makers frequently cited this connection in U.S. public statements and in congressional testimonies as one of the main justification for large military aid programs for Turkey. ${ }^{19}$ As a strategic barrier between the Soviet Union and the Middle Eastern countries Turkey played a crucial role in preserving stability in the region and neutralising the potential risks of the area for world peace and U.S. global strategy in the context of the East-West conflict. Amcrican Assistant Secretary of Defence Richard Perle's speech to a Senate committee is illuminating in this context: 'If the United States is unable to keep the Soviet Union's massive maritime capability bottled up in the Black Sea, the balance of power in the Eastern Mediterranean in a conventional war could and almost ccrtainly would shift against the United States. 20 The new developments such as the high increases in oil prices, the Iranian revolution and the invasion of Afghanistan by the Soviet Union led American officials to appreciate better Turkey's role in deterring the Soviet adventurism, preventing a decrease in the American influence in the region and protecting the West's access to oil in the Gulf. 21 Former American ambassador George McGhee supports this vicw: The fluid situation in Afghanistan since the Sovict withdrawal, the withdrawal of Iran from cooperation with the West, and the uncertainty regarding the Greek NATO commitment leave Turkey as the only reliable element in the northern tier of the Middle East. 22 In the light of these facts, it was natural to conclude that the United States had as much to lose as Turkey from breakdown in the bilateral relationship and that since Washington's leverage

${ }^{18}$ S. C. Pelletiere, "Ortadoğu'da Türkiye ve Amerika: Kürt Bağlantısı", Avrasya Dosyası, Vol. 1(3), 1994, p. 176.

${ }^{19}$ Rustow. Turkey, pp. 108-111; Steams, Entangled Allies, pp. 52 and 150; McGhec, The US-Turkish, p. 176; The Economist, 'Star of Islam', 14.12.1991, p. 4.

20 Bruce, 'Cyprus...', p. 117.

${ }^{21}$ Kuniholm, "Turkey in the World', p. 14; Rubin, 'U.S. Middle East Policy...', p. 79; Haass, 'Managing...' p. 465; Bruce, 'Cyprus...', p. 116.

${ }^{22} \mathrm{McGhee}$, The US-Turkish, p. 177. 
with Turkey was limited, any heavy-handed pressure of the Americans on the Turks could backfire.

When the Cold War came to an end with the collapse of the Eastern bloc and the Soviet Union, some doubts began to emerge on the strategic importance of Turkey for the West. Particularly Turkish officials seemed to concem that international developments could weaken Turkey's diplomatic leverage in Washington and that this could bring about a sharp reduction in U.S. military and economic assistance allocations for Turkey and a greater Greek influence over U.S. policy-makers on the issues relating to Turkish interests. These concerns led Turkish officials to emphasise repeatedly Turkey's role as NATO's only Muslim member in promoting stability in the Middle East and improving mutually beneficial economic relations between the West and the Muslim World. In the eyes of Turkish leaders, instabilities and conflicts in the Caucasus as well as the Middle East, uncertainties in the former Soviet republics and competitions for oil and gas reserves of the Central Asia had reinforced the importance of Turkey as a stable, democratic, secular and Western oriented state located in the region. The Americans had to reassure 'the Turks that as long as the geography of the region remained unchanged, so would Turkey's strategic importance. ${ }^{23}$ The Gulf Crisis of 1990-1991 proved that the end of the Cold War had not changed the crucial position of Turkey in the global strategic interests and initiatives of the big powers. The United States needed reliable access routes to the Middle East and Turkey's land, sea and air spaces commanded the best Westem approaches to the region. ${ }^{24}$ The U.S. bases in Turkey, too, continued to be valuable assets for the U.S. defence with their key roles in supporting America's Middle East policy and in monitoring abnormal military activities around that region.

\section{Cooperation in the Military Area}

The changes in the 1980s such as the Iranian revolution and the Soviet invasion of Afghanistan and the uncertainty prevailing in nearby Iran, Iraq, Syria, Lebanon and even in Greece strengthened the Turkish-American cooperation in the security area. ${ }^{25}$ As Richard Perle states, there were eighteen to twenty matters that were being worked on in harmonious fashion between the two states at the end of 1984 and it had been possible to resolve such delicate matters as the strengthening of the structure of NATO facilities

${ }^{23}$ Stearns, Entangled Allies, p. 130; 1. C. Acar, Dış Politika, Ankara, 1993, pp. 92-93.

${ }^{24}$ Stearns, Entangled Allies, pp. 51 and 149; B.R. Kuniholm, "Turkey and the West', Foreign Affairs, Vol. 70(2), 1991, p. 36.

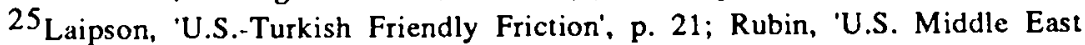
Policy..., p. 78 . 
in Turkey and Turkey's role in assisting the Multi-National Force in Lebanon. 26 Training programs and joint ventures in military production carricd out by Turkey with Saudi Arabia and Egypt were serving U.S. interests by contributing the Gulf stability. A major step in the cooperation of the two countries was the projected Turkish-American coproduction of F$16 \mathrm{~s}$ in Turkey. In a ten-year period, $160 \mathrm{~F}-16 \mathrm{~s}$ worth $\$ 4.2$ billion were to be produced. 27

In October 1982, the Turkish and U.S. officials signed a co-locator operating base agreement, which would provide for the modernisation of ten Turkish airficlds and the building of two new ones at Mus and Batman, in eastern Turkey. These airfields were to be large enough to accommodate long-range bombers and cargo planes and would place American and NATO aircraft within 700 miles of the Gulf and within striking distance of the Transcaucasus, thus cnhancing Turkey's role in deterring aggressive Soviet intentions against the region. The agrecment would make Turkey more valuable not only as a part of NATO's southern flank, but also as a possible base for rapid deployment in the case of a Middle Eastern crisis. American officials would like a clearer commitment on the use of the bases by the Western forces in contingencies involving the Gulf. But the Turks were understandably reluctant to permit the use of the airficlds for one-sided Western interventions in regional matters. Although pleased with the improved bilateral relations, the Turkish authorities were sceptical about the idea that the United States saw a potential role for Turkey in the Gulf and they feared that a U.S. move from the bases against the region could involve Turkey in some military conflicts and attract hostilities of the regional powers, with which Turkey had growing trade relations. Turkish officials repeatedly declared that the 1982 agreement had no connection with the Rapid Deployment Force and that use of the airficlds would be limited strictly to NATO missions. It seems that the Turks wanted to reserve the right to join or stand back from any possible Western intervention in the region, but they had no reservations on protection of the Middle East against a Sovict military push across Iran toward the Gulf. 28 In the following years, the U.S. preoccupation with preventing local uprisings and conflicts in the region which could harm U.S. interests underlined Turkey's vital place in American defence strategies as a possible base for rapid deployment of Amcrican forces. The Economist stated in Decomber 1991: 'It is uscful that the United States

26 Perle, 'Turkey and..., p. 23.

27 Rubin, 'U.S. Middle East Policy...; p. 79; Acar, Dış Politika, p. 92.

${ }^{28}$ Kuniholm, Turkey and NATO... pp. 438-439; Kuniholm, "Turkey in the World', pp. 14-15; William Hale, 'Turkey, NATO and the Middle East' in Richard Lawless (ed.), Foreign Policy Issues in the Middle East, Durham: University of Durham, 1985, p. 57; Kuniholm, "Turkey and NATO.... pp. 113-114; Perle, 'Turkey and...' p. 26; Rubin, 'U.S. Middle East Policy...' pp. 77-79; Haass, 'Managing...', pp. 465-468. 
is strengthening the force of bomber aircraft it keeps in south-eastem Turkey, to discourage present and future Saddam Husseins', ${ }^{29}$

There were some other matters which affected the U.S.-Turkish military cooperation negatively. The competition and deadlock between Greece and Turkey within NATO hampered their cooperation with the United States. Since 1984, the two states vetoed each other's 'national chapters', the yearly inventory of forces assigned to NATO, which served as a basis for NATO planning and for the alliance's annual 'Comparison of NATO and Warsaw Pact Forces', a document that was not published after 1984 for this reason. In 1987 and 1988, objections of Turkey and Grecce to specific projects proposed for infrastructure funding on each other's territory ended with failure to approve about half of the projects.

Since Turkish leaders believed that security policies of the United States were influenced by domestic political considerations which were under strong pressures of the anti-Turkish forces, they came to the conclusion that doing business with the U.S. government was full of uncertainties and that therefore Turkey should try to use NATO as a safeguard against over-reliance on the United States. ${ }^{30}$ In the Turkish eyes, although the United States was the strongest guarantee for Turkey's security, Turkey should have alternative sources of security and military equipment in the case of having serious problems with the USA. The Turkish worries on the excessive American tilt toward Iraq in the 1980s, which was thought to have a potential to push Iran toward the Soviet Union or causing instabilities in the region and the tough Turkish bargaining on the kind of access to Turkish facilities the United States would enjoy, too, showed how the U.S.-Turkish cooperation was far from smoothly operating. The criticism of the security partnership of Turkey with NATO and the United States by the Turkish opposition was another negative factor. It was claimed that although Turkey undertook a heavy burden for Western security by keeping a large army which required allocating large amounts of economic sources, she did not get any reasonable advantages in return and she had no voice or influence on the decisions taken within NATO. The Americans had the last word in Turkey's security matters and they had not allowed Turkey to use its armed forces for her own national interests. 31

From their alliance with the United States, Turkish authoritics expected that they would be given adequate assistance in arms and training and hoped that the Americans would provide supplies and reinforcements in

${ }^{29}$ The Economist, 'Star of Islam', p. 4.

${ }^{30}$ Stearns, Entangled Allies, pp. $68-69$ and 81 .

31 Necmettin Erbakan, Türkiye'nin Temel Meseleleri, Ankara: Rehber, 1991, pp. 53-54. 
the event of war. In their eyes, there should be no doubt whatsoever of America's commitment to fulfil its solemn obligations to Turkey if her security were threatened. The Turks also expected that their views would be considered in NATO councils before important decisions were taken. On the other hand, Turkish authorities appreciated the American support during their domestic difficulties in contrast with the European criticism, which led the Turkish government to withdraw from the Council of Europe's Parliamentary Assembly in 1982. Meanwhile, Amcrican officials were of the opinion that the special relationship between Turkey and the United States was on the solid ground and would continue in a foresecable future though it was inevitable to have ups and downs on the Cyprus and Armenian issues. ${ }^{32}$

\section{The Israeli Dimension}

The closeness of Turkey's relations with Israel was a factor which strengthened the U.S.-Turkish cooperation. Turkey and Israel were the closest allies of the United States in the Middle East and their encmies coincided with those of the USA. The Americans saw these states as the most important partners which would help the establishment and maintenance of a future Middle Eastern pcace and the protection of the American interests in the region. The Americans would like to sce that Ankara adopt policies which would improve its relations with Isracl. ${ }^{33}$ For the American Congress, Turkey's relations with Israel was an important matter which needed special attention. Congressmen became concerned about occasional reports that Turkey might reduce its relations with Israel. ${ }^{34}$

Since Israel was an indispensable partner of the West in the Middle East, Turkey could not completely contradict the Western positions on Israel as long as she remained active in European institutions and received economic and military aid from the United States. ${ }^{35}$ Although Turkey kept its relations with Israel cool in the 1980-1982 period to gain Arab support in the Cyprus conflict and to be in a better position in getting oil, the concern of both states on Syria's Sovict-backed policies attracted them to each other. In the early 1980s, Israeli and Turkish experts had began to secretly exchange information in their common fight against terrorism. The full cooperation of

32 Kuniholm, Turkey in the World', p. 12; Kuniholm, Turkey and NATO..., p. 444.

33 Kuniholm, 'Turkey and NATO..., pp. 114-115; Hasan Köni, 'Yeni Uluslararası Düzende Türk-Amerikan llişkileri', Yeni Türklye, No. 3, 1995, p. 434.

${ }^{34}$ Laipson, Turkey and the US Congress', p. 32.

$35 \mathrm{M}$. H. Yavuz and M. R. Khan, Turkish Foreign Policy Toward the ArabIsraeli Conflict: Duality and the Development (1950-1991)', Arab Studies Quarterly, Vol. 14(4), 1992, p. 81. 
Turkish law enforcement authorities with their Isracli and American counterparts during the terrorist bombing of the Istanbul synagogue in December 1986 pleased both the Americans and Israelis. ${ }^{36}$ Before the Gulf Crisis erupted Turkey had gone a good way in improving its relations with Israel in trade and intelligence. It seems that the first signal for the new momentum of the Turkish-Israeli relationship came from Washington. The American Jewish lobby followed Israeli instructions on supporting Turkey against the campaigns of the Armenian and Greek lobbies in Congress. ${ }^{37}$ The growing defence dimension of the Turkish-Isracli cooperation in the following years seemed to have the potential to be one of the most important bases of the U.S.-Turkish relations.

\section{The Economic Aspect}

The United States naturally wants Turkey to shape its economy under a free enterprise market system, together with a liberal international economic policy. Therefore Turgut Özal's market-oriented cconomic reforms were bound to be welcomed in Washington. Özal's liberal revolution had the characteristic of being an American answer to Turkish problems: 'privatisation of state enterprise; economic mobility of capital and labour across frontiers; televised contests among political leaders and bids for the second Bosporus bridge thrown wide open to international competition. 38 These reforms made Turkey in the 1980s particularly attractive for American and European investments in agribusiness, processed foods, textiles, electronics manufacturing and regional banking.

Meanwhile, Turkey's rapid economic development progressed to the point where Turkish leaders preferred more trade to aid in their dealings with the United States. Since he saw a strong economy as the most important condition for maintaining national security, Özal tried to encourage foreign and domestic investment in Turkish economy and to build a national military industry. In these efforts, opening the U.S. market to Turkish goods, especially textiles, and having advantageous partnership arrangements with the U.S. industry had a great importance. ${ }^{39}$ One problem in this regard was the quota established by the American authorities for the Turkish textile imports to the United States. During his visit to Turkey in March 1986, American Secretary of State Shultz was informed of the Turkish demand that

${ }^{36}$ Rustow, Turkey, pp. 115 and 133 n.

37 Yavuz and Khan, 'Turkish Foreign Policy..., pp. 81-82.

${ }^{38}$ Rustow, Turkey, p. 124.

39 Ibld., p. 106, Yavuz and Khan. Turkish Foreign Policy.... p. 83; Acar, Dış Politika, p. 92; Köni, 'Yeni Uluslararası...' p. 435; Henze, 'Out of Kilter', p. 82. 
the new DECA be linked to a substantial increase in this quota. 40 The imbalance in the U.S.-Turkish trade, proved by the Turkish export to the USA worth $\$ 534$ million in contrast with $\$ 1.7$ billion U.S. export to Turkey in 1991, caused the demands on the Turkish side in the direction of abolishing this inequality. 41 While not getting any positive results on the textile quota and trade imbalance issues, the U.S. support for Turkey's future membership in the European Community was one valuable development for Turkish leaders. Turgut Özal had made Turkey's EC membership one of the main objectives of Turkish foreign policy and now the United States could show its friendship by assisting Turkey in this matter even if this could be materialised at the expense of U.S. bilateral trade with Turkey. ${ }^{42}$ The Bush administration particularly put emphasis on this matter to gain the Turkish support during the Gulf crisis of 1990-1991.

\section{The Ideological and Cultural Aspect}

The United States generally would prefer that Turkey adopt a true parliamentary democracy and try to protect and improve it. Turkey's chief value for the West was to be an example to the region around it. Turkey would demonstrate that a Muslim country could become a prosperous democracy and a full member of the modern world. ${ }^{43}$ During the 1980 s, Turgut Ozzal symbolised the revival of democracy in Turkey. But there were still doubts in the minds of the Americans on Turkey's future: 'Might Turkey's still somewhat precarious balance between military and democratic politics be upset by future waves of terrorism and by a renewed combination of economic crisis and parliamentary deadlock'; and thus might Turkey come under the military control again? More importantly, 'might future Turkish citizens become more susceptible than were their parents to the appeals of Islamic fundamentalism?' 44 While improving its democracy and protecting itself against Islamic movements, Turkey should exert its leadership abilities over the regional states which experienced conflict with the West in recent years and should take advantage of its membership in the Islamic Conference Organisation to help disrupt 'the efforts being made by Iran's Ayetollah Khomeini to desecularise the Islamic world and make it a base for a modernday religious war against the West. ${ }^{45}$ Since the American authoritics hoped to replace Turkey's role as a guardian of the southern flank of NATO with

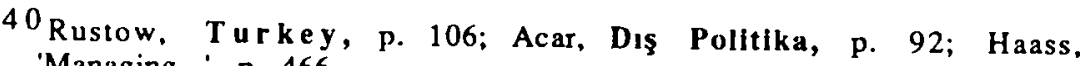
'Managing...', p. 466.

41 Acar, Diş Politika, p. 92.

${ }^{42}$ McGhee, The US-Turkish, p. 180; Pelletiere, 'Ortadoğu'da Türkiye..., p. 180 .

43 McGhee, The US-Turkish, p. 176; The Economist, 'Star of Islam', p. 4.

${ }^{44}$ Rustow, Turkey, p. 116.

45 McGhee, The US-Turkish, p. 176.
} 
'the mission of serving as a secular pro-Western alternative to Iran's Islamic assertiveness in the region', ${ }^{46}$ as Newsweek stated, Washington had been 'actively courting Turkey as its chief secular ally in a region threatened by the rise of Islamic fundamentalism. ${ }^{47}$

Özal's efforts in the final months of his presidency to link Turkey with ethnically Turkic republics of the former Soviet Union in a union loosely modelled on the British Commonwealth, ${ }^{48}$ brought about the possibility of Turkey's initiating campaigns in the Central Asia on behalf of the West against the moves of the 'fundamentalist' Saudi Arabia and Iran. The American think-tank institutions were suggesting that the United States should support the Turkish initiatives because Turkey was a secular state which had Westem-oriented policies, a free-market economic regime and close cultural and ethnic ties with the Central Asian nations. Turkey's bold initiatives in the region in the early 1990s in spite of its scarce resources shows that Turkish authorities had strongly expected American aid and support. ${ }^{49}$ In the following years the apparent convergence of American and Turkish interests in Central Asia became a constant factor of the general U.S.-Turkish cooperation.

One issue which caused complaints against the Turkish government was Turkey's drastic actions in facing the Kurdish terrorism. As the European states directed more human rights accusations against Turkey on the Kurdish question, the American authorities seemed to appreciate Turkcy's quite extraordinary success in coping with anarchy and terrorism. Nevertheless, the Americans, especially Congress, joined the others in urging Turkish rulers to take impressive steps in restoring democracy and parliamentary government and respecting human rights. ${ }^{50}$ It seemed that Turkey's alleged occasional departures from the democracy and human rights standards advocated in the United States would have an impact on relations between the two states. In spite of their common interests and similar democratic institutions, it was a fact that the Turkish and American nations differed in ethnic, religious, political, geographic and historical background. However, apart form minor disagreements, it was hard to attribute the major issues between the two states to these mainly ideological and cultural factors. ${ }^{51}$ It could be fair to state that these factors affected the degree of the U.S. Congress' reactions on

${ }^{46}$ Yavuz and Khan, Turkish Foreign Policy... , p. 86.

47 Newsweek, 06.04.1992, p. 15.

48 Newsweek, 26.04.1993, p. 13.

${ }^{49} \mathrm{Köni,} \mathrm{'Yeni} \mathrm{Uluslararası...,} \mathrm{p.} 429$.

50 Perle, 'Turkey and...' p. 25; McGhee, The US-Turkish, p. 167; Laipson, Turkey and the US Congress', p. 31.

51 McGhee, The US-Turkish, p. 161. 
some issues or they were used as a pretext for making life difficult for Turkey.

Turkey's Islamic connection, too, had the potential to be a straining force in its relations with the United States. Turkish leaders had to emphasise Turkey's Islamic identity to gain support of the Muslim world for Turkey's economic growth and some important objectives of her foreign policy. In the late 1970s, the Turkish government had refused to join the American-led economic and diplomatic sanctions against Iran following the Islamic revolution and the captivity of American diplomats in Iran. 52 Turkey's increased political and economic interactions with the Muslim countries in the 1980 s were initiated by the military regime. Turkish efforts to become more deeply involved in the Middle East, which required altering its image as an American proxy, caused a slight coolness in the U.S. Turkish relations even during the Reagan administration period in comparison to earlier periods. 53

\section{Greek-Turkish Differences}

The Greek-Turkish disagreements over such issues as the boundaries of territorial waters and continental shelf, the control of airspace, surface navigation and oil rights in the Aegean, where many Greck islands lie within sight of the Turkish coast, inevitably affected the Turkish-American cooperation, too. American authorities tried to avoid involvement in these disputes, but their actions or failure to take actions were often criticised by both sides. ${ }^{54}$ In March 1987, the indications that Greece might be planning to explore oil in the parts of the Aegean which were considered as international waters by Turkey led Turkish leaders to send a research vessel of their own into the same area. The United States and NATO were then obliged to intervene in the matter to prevent an armed conflict between the two sides by persuading them staying outside the disputed arca. ${ }^{55}$ It seemed that these kinds of crises would irritate the Americans in the future as well, by putting them in a difficult position to prevent a conflict between their two allies not to cause instability in a strategic region.

The Cyprus question was another negative factor affecting the U.S.Turkish relations. As the American side tried not to lose its influence on Cyprus, located in a strategic place, by adding the Cyprus-related conditions to U.S. military interactions with Turkey, this shook the Turkish confidence in the USA. After the Turkish arms embargo was lifted in 1978, the

52 Yavuz and Khan, Turkish Foreign Policy..., pp. 76, 78.

53 Bruce, 'Cyprus...', p. 131.

${ }^{54} \mathrm{McGhee}$, The US-Turkish, p. 161.

55 Stearns, Entangled Allies, p. 126. 
American administrations had to submit bimonthly reports to Congress certifying that progress was being made toward a Cyprus settlement. ${ }^{56}$ When the Turkish side declared statehood on northem Cyprus, both chambers of the American Congress condemned the declaration and called on the Administration to try to reverse that was viewed as a dangerous move by the Turkish Cypriots. The American aid bill in 1984 tied the U.S. aid to Turkey to the presidential certification that (a) the U.S. government was acting to prevent moves to partition Cyprus and was calling on Turkey to take stcps to reverse the independence of Northem Cyprus and (b) Turkey was making efforts to insure that the Turkish Cypriots took no action in Varosha that would impede negotiations on the future of Cyprus. 57 These were unacceptable conditions to the Turks.

Since Cyprus-related tensions kept alive the possibility of a disastrous war between the two NATO allies, and led these countries to spend cnormous amount of money and energy, thus threatened the stability of the region, the Americans put pressures on both sides to find a permanent solution to the problem. American President Reagan's letter to Turkish President Kenan Evren on 22 November 1984 warned that the U.S. administration might not be able to overcome congressional opposition in the future. The letter persuaded Turkish officials to reduce their demands for territory from 37 percent to 29 percent, drop the idea of a rotating presidency and soften their insistence on absolute veto rights in all institutions of government. 58 The American insistence on the solution of the Cyprus question and the Turkish failure to fulfil this demand because of the complexity of the problem and the sensitivity of the Turkish people toward Cyprus have always cast a shadow on the U.S.-Turkish relations, which would not disappear in the near future.

\section{The Armenian Issue}

Another problem that affected the U.S.-Turkish relationship was the continuing effort of the Americans of Armenian descent to persuade some Congressmen to introduce resolutions which sought to establish a day of remembrance to commemorate 'man's inhumanity to man', calling particular attention to the alleged genocide of Armenians at the hands of the Ottoman Turks early in the twentieth century and somehow associating the present-day Turkish Republic with those events. While the Armenians launched propaganda campaigns and lobbying for Congressional actions censuring Turkey, more then 50 Turkish diplomats in a number of countries were assassinated by the Armenian Secret Army. The Turkish government reasoned that many pcoplc along with the Armenians died amid the

\footnotetext{
56 Ibid., p. 125.

57 Laipson. 'Turkey and the US Congress', pp. 29-30.

${ }^{58}$ Bruce, 'Cyprus...', pp. 115-116,119,129 and 133.
} 
breakdown of order during the World War I, especially because of the encouragement of the Armenians by the Soviets and later by the Western powers to set up an independent state, but no genocide-type killings occurred. ${ }^{59}$ Turkish officials argued that Armenians were using the issue just as an excuse to justify their terrorist campaigns against Turkey and the U.S. Congress was encouraging them with its resolutions on the issue.

To scale down the Turkish anger, the Americans stressed that nonbinding resolutions passed by Congress did not constitute major U.S. forcign policy pronouncements and that they were not connected directly to the foreign aid legislation or to the general tone of the U.S.-Turkish cooperation in security and defence matters. ${ }^{60}$ There were Americans who suggested that the Turkish government might recmphasise 'Atatürk's repudiation of the Ottoman mass killings of Armenians' or who criticised the Turkish press on the ground that its behaviour blew the issuc out of proportion and 'made as though a good and faithful ally the USA-was any way departing from a desire for close and continuing constructive relations with Turkey'. 61 However, there was no doubt that mere introduction and consideration of Armenian resolutions had become a major sore point in the U.S.-Turkish relationship and that, as one American author admits, 'to dwell on a one-sided picture of the past' would not help improve America's relations with its key Atlantic-Middle Eastern ally and Armenian terrorism was 'one of the prime means by which Moscow and Damascus' hoped 'to drive a wedge between Turkey and the West.' 62

\section{Conclusion}

As it has always been the case, the military and security aspect constituted to be the most important part of the U.S.-Turkish relations during the 1980s as well. Located in a strategic and unstable region which always attracted the attention of big powers, Turkey found a great advantage in having alliance relations with the leader of the West, in spite of its unhappiness on some important issues. The conditioning of the U.S. aid by Congress to the Cyprus and Armenian issues, the Turkish-Greek differences and human rights was particularly hurtful for Turkish leaders and led them even to think about alternative security partners. In spite of their failure in getting positive results from negotiating the extension of the DECA, in changing the negative attitude of the U.S. Congress, in overcoming the 7:10

${ }^{59}$ Rustow, Turkey, pp. 101-102; McGhee, The US-Turkish, pp. 167-168; Haass, 'Managing...', p. 466.

${ }^{60}$ Laipson. Turkey and the US Congress', p. 33; Perle, Turkey and..., p. 24; Rustow, Turkey, p. 103.

61 Perle, "Turkey and... p. 26; Rustow, Turkey, p. 103.

62 Rustow, Turkey, p. 103. 
ratio and in abolishing the U.S. textile quotas and the imbalance in the U.S.Turkish trade, Turkish leaders' cooperation in providing the legal basis of the U.S.-Turkish security relations proved their appreciation of America's alliance, but it also gave signals for the possibility that they could play it hard against the Americans when they felt it necessary.

Turkey's strategic location at the cross-roads of important and unstable regions such as the Middle East, the Central Asia and the Balkans always made her an indispensable element for the Americans. As Turkey had served as a barrier against foreign interventions in the Middle East in the past, with new developments, she could play an important role in providing the Western access to the Gulf oil and could serve as a base for rapid deployment of Western forces in the case of regional crises affecting Western interests. Being an example for regional states against fundamentalist Islamic movements and establishing close ties with Israel were new roles of Turkey, which gained importance for the Americans. Turkey's unwillingness to involve itself in one-sided Western initiatives in the Middle East, the possibility of a Greck-Turkish war on the Cyprus and the Aegean issues, excessive Turkish demands on the military area, and Turkey's different historical background together with the possibility of Turkey's inclination to the Muslim world with the development of conservative movements were main sore points of America's relations with Turkey. In spite of all negative elements, the U.S.-Turkish cooperation during the 1980 s was much stronger than that of the 1970s. 